\title{
Legal Reconstruction of State Institutionalities of State Commissions to Suppress the Potential of Institutional Authority Dispute
}

\author{
Lukman Hakim *
}

Universitas Widyagama Malang, Indonesia

\begin{abstract}
The main problem of this research triggers by the fact that Indonesia fundamental constitutional system changed into the 1945 Constitution. The changes affected the structure and structural mechanism of state institutions. The main purpose of this study is to analyze the philosophical question of the basic root formed in the 1945 Constitution as a new constitution of Indonesia. Regarding the organization and institution of the state can be started by questioning the essence of power that is institutionalized or organized into the state. The results showed that it is also important to know how the principle of popular sovereignty is reflected in the structure and mechanisms of state and government institutions that guarantee the establishment of the legal system and the functioning of the democratic system. At the theory level in terms of state institutions, with the various state commissions, how the principle of popular sovereignty is organized into institutional functions can be patterned into state institutions that are equal and mutually balanced in forms of checks and balances. From a normative perspective, the sources of state institutional authority can be used as a reference in the structuring of state institutions by considering shifts and the development of state administration, especially with the state commissions that occurred after changes to the 1945 Constitution.
\end{abstract}

Keywords: Legal reconstruction, state institutions, authority, legal dispute, state commission.

\section{INTRODUCTION}

There was a fundamental change of power-sharing in the three branches of power, i.e., executive, legislative, and judicative, after the amendment to the 1945 Constitution (Jundiani, 2010). It brought an extensive change of the state institutional structure, and the amount became more than before the amendment (Ismail, 2019). There is no more supreme state institution since all of the state institutions are equal and independent with their authorities (Mulyani, 2016). The amendment to the 1945 Constitution, even though it has changed the design of the state institution, has not yet accommodated the rapid development of the state commission. Some state commissions formed outside the provisions of the constitution are often referred to as 'state institutions.' The unclear constitutional system which brought the existence of this state commission generated public hesitation (Lutfi \& Satriawan, 2013). Moreover, the affirmation of the principle of checks and balances among the state institutions in the exercise of power increasingly opens up space for disputes to emerge (Mukhlis, 2011). This dispute is possible because the system of relations between one institution and another adheres to the principle of checks and balances, which means equal but supervising each other equally (Safi', 2016). The institutionalization of independent

*Address correspondence to this author at the Universitas Widyagama Malang, Jl. Borobudur No. 35, Malang, East Java 65142, Indonesia; Tel: (0341) 492282; E-mail: lukmanhakim.widyagama@gmail.com state commissions began to dominate at every stage of legal development. This symptom is almost endemic in every country that carried out constitutional reform after undergoing a process of transition from authoritarian to democracy (Arjomand, 2003). The presence of new state institutions, including state commission known as state auxiliary organs, is the consequence of the redistribution of power that was personal in the past, developing towards impersonal (Rishan, 2018). Moreover, these independent state commission agencies, if judging from its nature and authority, in some state administration law in America is called the Fourth Branch of Government (Arbani, 2018).

The lack of clarity affects the process of structuring state institutions and democratic governance. For this reason, in the context of the existence of this state commission in Indonesia, its regulation needs to be established within the framework of the Indonesian constitutional system, and at the same time in the framework of developing a national legal system that further guarantees justice and democracy in the future (Putra, 2020). To understand the state commission, which includes its definition, concept and institutions, we must see it see on a new paradigm of the state system, which has been realized in the amendment of the 1945 Constitution as a manifestation of the will of the people and democratic ideals (Wiriadinata, 2013). From the perspective of the state, the formation of the state commission must have a solid foundation and clear paradigm. So, its existence brings benefits to the public interest in general and the structuring of the 
state institutional system in particular. Specifically, this study analyzes the reconstruction of state institutional law in the presence of new institutions in the form of state commissions. This study considered the legal reconstruction of state institutional agencies. Besides, it also analyzes the implications that must be anticipated from the reconstruction of state institutional law, especially in suppressing potential disputes over state institutional authority.

\section{LITERATURE REVIEW: STATE INSTITUTIONAL CRITERIA}

Along with the demands for democratization, the relevant changes are related to the general election for members of the DPR, DPRD, DPD and the President as regulated by article $22 \mathrm{E}$ junto article $22 \mathrm{C}$, article 19 , article 6 A (1), Article 2 (1) of the 1945 Constitution. The changes in the presidential election have consequences for the People's Consultative Assembly (MPR) position. Before the change of the 1945 Constitution, the President elected by the MPR and with the direct election in filling the position of President would reduce the authority of the MPR. The relationship between the President and the MPR, which places the President as a mandate of the MPR, cannot be sustained after the amendment of the constitution. It is because the MPR does not elect the president any longer. This has an illogical consequence if the President is responsible for MPR because the President's legitimacy is obtained from the people directly through elections and not from MPR. The relationship of the President's accountability to the MPR in the past was carried out by assessing the President's performance in implementing the State Policy Guidelines (GBHN). The amendment of the constitution eliminates the President's accountability relationship to the MPR, which was previously carried out through an assessment mechanism for the implementation of the GBHN. The authority of the MPR, which was originally the executor of the whole, is the sovereignty of the people which includes; determine the constitution, amend the constitution, elect the President and Vice-President, determine the GBHN, and hold the President accountable to be reduced by the changing of the constitution. The main authority of the MPR according to the constitution after the amendment is as a constituent to establish and amend the constitution and the additional authority granted by the constitution is to elect a Vice President if the position is empty before the term of office expire in five years (article 8 (2) of the constitution). The same case also applicable if President and Vice President cannot fulfil their duties (Article 8 (3) of the constitution).

Direct regulation is carried out by a general election to form institutions that will apply people's sovereignty through representative institutions. The institutions that will be formed based on the general election are; DPR (Parliament), DPD (Regional Representative Council), and President. These three institutions become important elements in the implementation of democratic institutions through representation. DPR members are elected in the general election in cooperation with the President who is also elected in the general election will produce a legal Act (article 5 jo article 20 of the 1945 Constitution), while members of the DPR and DPD members together form the MPR institutional (article 2 paragraph (1) 1945 Constitution) which the main function is as a constituent assembly to establish and amend the constitution.

Thus it can be concluded that representative democratic institutions in the amended constitution rest on three pillars; DPR, DPD, and President. The position of the President in the constitution before the change is the mandate of the MPR. After the amendment of the 1945 Constitution since the President was directly elected by the people, the President has a value of the deputy voters. President gets direct legitimacy from the people as well as DPR and DPD, so the position of Vice President is higher than members of DPR and DPD.

Based on the considerations above, DPR, DPD, MPR, and President in the 1945 constitution are implementing agents of democratic institutions. If the classic institutional approach in the trias politicia Montesquieu applied, President, has executive power. However, this classic approach cannot be applied to the DPR, DPD, and MPR institutions. As we all know, besides executive power, there are also state institutions that implementing legislative power.

DPR, DPD, and MPR are not appropriate if they have absolute legislative power. Even though it is mentioned in article 20 paragraph (1) that the DPR has a right in lawmaking, however, DPR is not the only institution that has that authority because lawmaking requires approval from the President (article 20 paragraph (2) of the constitution). Thus it is not appropriate that the legislative institution, according to the 1945 Constitution, is only DPR. This is different from the American system, which places Congress as the implementing agency for legislative power. 
Although Congress consists of two elements, House of Representatives and Senate, Congress itself is a name of a state institution. This is different from the making of laws in the 1945 Constitution, President and DPR are separate state institutions. The composition of the MPR is similar to the American Congress, which consist of two components, but still have differences. Congress is known as a bicameral system because it consists of two separate institutions. MPR does not consist of two separate institutions because MPR membership consists of DPR members and DPD members. As a result, in MPR, there is only one decision-making mechanism, namely MPR decision-making. There are multiple parallel systems in decision-making in a bicameral system because each institution has its decision-making mechanism.

Another problem will also arise if the division of powers is classically applied to the MPR, there will be a confusion whether MPR called an institution or a legislature. If MPR is included in the legislative power branch, as a consequence, the 1945 Constitution will have more than one legislative power besides the DPR. MPR has the main authority to determine and amend the constitution. The application of classical teachings on branches of state power in the American Constitution does not cause problems as the application of these classic teachings in the 1945 Constitution. Amendments of the American Constitution are not the duty of state institutions. Meanwhile, the 1945 Constitution gives MPR authority for the amendment, but to amend the American Constitution is using convention institutions, which are institutions that involve federal state institutions and state institutions from existing states and without forming a special state institution for that.

The theory of separation of powers cannot be applied to the 1945 Constitution. Lawmaking is not carried out by special branches of power for this purpose so that it is separate from other branches of power since lawmaking is the authority of DPR and the President. The American Constitution gives the authority to make laws exclusively to Congress instead of state institutions, which also have another duty. The existence of veto institutions is intended as a 'check and balances' mechanism, with this mechanism President as the executive who will implement the Act has the opportunity to give feedback on the law that has been made by Congress. The veto facilities owned by the President are no longer needed in the making of laws according to the 1945 Constitution after the amendment because the President was directly involved from the beginning in making the law. This involvement is stronger than veto institutions (article 20 paragraph (2) of the constitution). This description provides the grounds that the classical theory of the distribution of power based on trias politicia and the theory of the separation of powers cannot be applied to analyze state institutions regulated by the 1945 Constitution.

\section{RESEARCH METHOD}

This research is a study of legal knowledge of the constitution in a broad definition, especially the state institution's aspect and its implications for the formation of the Republic of Indonesia's state institutional system. Therefore, the main approach in this research is the normative approach, which means an approach to the constitution can be found in positive legal rules containing state institutions and in various constitutional practices. Legal materials include primary legal materials, secondary legal materials, and tertiary legal materials. Primary legal material is all legislation relating to the institutional state commission. The research uses data collection techniques in the form of library research with note-taking, recording, and listening. The researcher used the library research to obtain secondary data in the form of primary legal materials, both in the form of statutory regulations, administrative decisions, decisions of the Constitutional Court and the Supreme Court, tracts in congregations from various state institutions, academic texts, bills or secondary and tertiary legal materials such as journals, research results, scientific publications, and books relating to the matter carefully. In-depth research was conducted at the Constitutional Court and the Supreme Court as the judiciary for resolving disputes over state institutional authority. The state institutions include State Institutions in Central government (Jakarta); State Institutions in Provincial level (Surabaya); State Institutions in City/Regency Areas (Malang); Constitutional Court and Supreme Court. For analysis, since the data target is juridical, the analysis is done by 'juridical qualitative analysis.'

\section{RESULTS: RECONSTRUCTING THE STATE INSTITUTIONAL LAW IN THE STATE CONTEXT}

The legal system, as a hierarchic unit of principles, norms, rules, and legal traditions that are selfreferential, is closed, coherent, and logical, with the constitution as the basic and highest rules. This concept of the legal system can be understood in parallel with the constitutional system, which is an 
embodiment of a constitution. Therefore, there is a correlation between the constitution, the constitutional system, and the legal system. The national legal system is "a part of a set of laws or interrelated legal sub-systems that form a complex or complex whole but is a unity" with the Pancasila and 1945 Constitution as the basic concept and determines the value system of the national legal system. Values in Pancasila as the basis create unity, unanimity, and the whole (entity). The values contained therein are a unity that in the national legal system (Muawanah, et al., 2018). Pancasila as the source of all sources of law has obtained legitimacy legally through the Decree of the People's Consultative Assembly Number XX/MPRS/1966 on the Memorandum of the House of Representatives-Gotong Royong Regarding the Sources of Law and the Order of the Republic of Indonesia (Bo'a, 2018).

Economic globalization competition and the demands of democratization is a common thing in the International association of nations. Globalization drives economic liberalization, and free markets cause cultural interactions between nations and have the potential to shape social values (Berggren \& Nilsson, 2015). It has dramatically altered business paradigms and government policies with unprecedented effects on societies and cultures, ecosystems and health, justice, and equality (Abdel-Hadi, 2012). It also influences change cultural patterns (Raikhan, Moldakhmet, Ryskeldy, \& Alua, 2014). Even now, in the fastchanging global digital economy, it has given rise to major legal reforms across nations (Kim, 2019). The changes in attitudes and behaviour in society, bring new demands and find new paths. In such circumstances, it must be anticipated and accommodated into the development, planning, and formation of the law through the structuring of the legal system.Indonesia must make arrangements in the planning and formation of national legal systems that is suitable for international trends. An important matter in structuring national law must pay attention to elements of international, sociological, philosophical, juridical, and practical-addictive elements. Related to that, facing the era of globalization, requires anticipatory thinking in structuring the legal system that can accommodate these international trends.

With those kinds of value systems, Indonesian have a clear value that will determine the direction and goal to be achieved. These values become a guide to life and provide guidance and determine the direction for the present and the future. These values also serve as a frame of reference for solving basic problems in law enforcement, including legislation planning, lawmaking process, law enforcement, and law awareness. Law awareness understood as part of legal culture. Thus, the national legal system absorbs a value system consisting of some interrelated values that originate from the view of the Indonesian nation's life match with a sense of justice (Nurhidayah \& Mcllgorm, 2019). The arrangement of a comprehensive and integrated national legal system is a must. It includes arranging a comprehensive and integrated national legal system by recognizing and respecting religious and customary law and updating discriminatory colonial legislation and national laws. These include gender inequalities and non-compliance with reforms through legalization programs. The national legal system that is imbued with Pancasila and is based on the highest positive law which is the 1945 Constitution and amendments of the constitution as 'the supreme law of the land,' which able to guarantee certainty, order, enforcement, and legal protection, which is centred in justice and truth. A system is a set of elements that influence each other. Positive law is structured in order, starting from basic law to the most concrete and individual laws must be based on a value system that contains ethical judgments. These values are found in the basic norms that bind the arrangement of positive norms as a whole. According to Hans Kelsen, "An 'order' is a system of rules. Law is not, as it is sometimes said, a rule. It is a set of rules having the kind of unity we found by a system. (Kelsen, 1973) Law is a set of laws and regulations that contain a kind of unity or binding power which is understood as a system. 1945 Constitution and Amendments of the Constitution, as well as all the legislative provisions for the elaboration and implementation, also have the unity or binding force of the Indonesian nation as a system within the state.

The national legal system is a national legal system that is structured based on the hierarchical and core ideology of Pancasila, which is operationalized into negotiations through the principle of national law in the process of establishing positive law through legislation and jurisprudence. Within principles of Pancasila become the source of norms. The norms are developed into a legal system, written legal system, and unwritten legal system. The national legal system stands over the principles, values that originate from the nation's view of life, and as a legal system with justice and the goals of the law (rechtsidee), agreeable with a sense of justice. The national legal system in 
legal politics is formed based on the Pancasila and 1945 Constitution, for the implementation of the state based on law and constitutional principles, and the realization of social justice for all people.

A conclusion from the concept above is drawn that 'the national legal system includes written law and unwritten law that arranged hierarchically operationalized into reality in the process of forming positive law through legislation and jurisprudence. It has philosophical principles contained in Pancasila and the constitutional principles in the 1945 Constitution'. The legal system includes elements of legal substance, legal and institutional structure, and legal culture. Thus, the framework of the national legal system includes elements of legal material consisting of external legal arrangements called legislation, unwritten laws including customary law and jurisprudence, as well as internal legal arrangements namely legal principles that underlie them; elements of the legal structure and institutions, consisting of various institutional bodies or public institutions with their officials; and elements of legal culture, which include the attitudes and behaviour of officials and members of the community to other elements in the processes of social life. The formulation of an ideal step in structuring the national legal system is an effort to harmonize, adjust, balance and consistency the elements of the legal system to integrate various legal systems to arrange a right order in the framework of the national legal system with placed Pancasila and sourced from 1945 Constitution and Amendments of the Constitution. Thus, the effort to arrange the national legal system is a 'conditio sine qua non' for ensuring legal certainty, law order, law enforcement, and legal protection with the core of justice and truth. The legal system of a country is a combination of legal theories in general by the way human groups form a nation-state in organizing "selfregulation" through the organization of their country. It could be characterized by whether a social change was primarily dealt with by legal fictions, equity or natural law, or conscious creative legislation (Clark, 2001). The procedures in regulating themselves can be found in the 1945 Constitution. The idea of Indonesian society is listed in the preamble of the 1945 Constitution; humanity and justice..

\section{CONCLUSION}

The results showed that reconstruction of state institutions based on state commissions can be classified in terms of law, politics, authority disputes, and the formation of new paradigms in the administration of state life. The existence of a state commission in the Republic of Indonesia's constitutional system has led to changes in design and new criteria in the structuring of the national legal system. The changes in the design of state institutions with the existence of a state commission greatly affect the life of democracy, especially at the time of the implementation of functions, which authority possessed in government power activities. Finally, the new paradigm of the existence of a state commission can be used as a basic reference in the administration of state life to build an established constitutional system of the Republic of Indonesia. The change in paradigm may involve the state's role in the life of the state, the system of organizing the state, the pattern of state relations, and institutionalization mechanisms, including the main function of state commissions in the context of a democratic rule of law. This new paradigm can be the basis for the future development of the nation-state of Indonesia.

\section{REFERENCES}

Abdel-Hadi, A. (2012). Culture, quality of life, globalization and beyond. Procedia Social and Behavioral Sciences, 50, 11-19. https://doi.org/10.1016/j.sbspro.2012.08.011

Arbani, T. S. (2018, June). Juridical analysis of the fourth branch of government in Indonesia constitutional structure. Wacana Hukum, 23(1), 19-37. https://doi.org/10.33061/1.jwh.2018.24.1.2996

Arjomand, S. A. (2003). Law, political reconstruction and constitutional politics. Journal International Sociology, 18(1), 9. https://doi.org/10.1177/0268580903018001002

Berggren, N., \& Nilsson, T. (2015, May). Globalization and the transmission of social values: The case of tolerance. Journal of Comparative Economics, 43(2), 371-389. https://doi.org/10.1016/j.jce.2015.02.005

Bo'a, F. Y. (2018, March). Pancasila as the source of law in national law system. Jurnal Konstitusi, 15(1), 27-49. https://doi.org/10.31078/jk1512

Clark, D. S. (2001). Legal systems, classification of. In N. J. Smelser, \& P. B. Baltes (Eds.), plnternational Encyclopedia of the Social \& Behavioral Sciences (pp. 8684-8689). Pergamon. https://doi.org/10.1016/B0-08-043076-7/02765-0

ICCE UIN Jakarta Team. (2003). Democracy, human rights, madani society. Jakarta: UIN Syarif Hidayatullah.

Ismail MZ, H. (2019, September). The analysis of state institution structure change and state governance of the Republic of Indonesia based on 1945 Constitution before and after the amendment. Ganec Swara, 13(2), 258-269. https://doi.org/10.35327/gara.v13i2.90

Jundiani. (2010, June). The authority of state institution after the amandement of 1945 Constitution. De Jure, Jurnal Syariah dan Hukum, 2(1), 1-11. https://doi.org/10.18860/j-fsh.v2i1.45

Kelsen, H. (1973). General Theory of Law and State. New York: Russels \& Russels.

Kim, H. (2019, October). Globalization and regulatory change: The interplay of laws and technologies in E-commerce in Southeast Asia. Computer Law \& Security Review, 35(5), 105315.

https://doi.org/10.1016/j.clsr.2019.03.009 
Lutfi, M., \& Satriawan, M. I. (2013). Observing the Public Information Commission. Malang: UB Press.

Muawanah, U., Yusuf, G., Adrianto, L., Kalther, J., Pomeroy, R., Abdullah, H., \& Ruchimat, T. (2018, May). Review of national laws and regulation in Indonesia in relation to an ecosystem approach to fisheries management. Marine Policy, 91, 150160.

https://doi.org/10.1016/j.marpol.2018.01.027

Mukhlis. (2011). The authorities of state institutions in deciding and interpreting constitution after the fourth amendment of 1945 Constitution. Syiar Hukum: Jurnal IImu Hukum, XIII(1), 46-66.

Mulyani, T. (2016, January). Normative review of the relation among the state institutions in the Republic of Indonesia constitutional structure based on 1945 Constitution: Before and after amendment. Humani, 6(1), 75-95. https://doi.org/10.26623/humani.v6i1.855

Nurhidayah, L., \& Mcllgorm, A. (2019, February). Coastal adaptation laws and the social justice of policies to address sea level rise: An Indonesian insight. Ocean and Coastal Management, 171, 11-18 https://doi.org/10.1016/j.ocecoaman.2019.01.011
Putra, S. G. M. S. R. (2020). Legal reconstruction of implementation legally binding verdict in industrial relations court. Jurnal Hukum dan Peradilan, 9(1), 99-115. https://doi.org/10.25216/ihp.9.1.2020.99-115

Raikhan, S., Moldakhmet, M., Ryskeldy, M., \& Alua, M. (2014). The interaction of globalization and culture in the modern world. Procedia Social and Behavioral Science, 122, 8-12. https://doi.org/10.1016/j.sbspro.2014.01.1294

Rishan, I. (2018, November). The relevance of inquiry right on the independent state commission. Dialogia luridica, 10(1), 4464. https://doi.org/10.28932/di.v10i1.1031

Safi'. (2016). The political law of unification of the authority of the judicial review. Yogyakarta: Diva Press.

Wiriadinata, W. (2013). Komisi Yudisial dan Pengawasan Hakim di Indonesia. Jurnal Hukum \& Pembangunan, 43(4), 530-545. https://doi.org/10.21143/jhp.vol43.no4.1502

Received on 08-03-2021

Accepted on 05-05-2021

Published on 11-05-2021

https://doi.org/10.6000/1929-4409.2021.10.118

(C) 2021 Lukman Hakim; Licensee Lifescience Global.

This is an open access article licensed under the terms of the Creative Commons Attribution Non-Commercial License (http://creativecommons.org/licenses/by-nc/3.0/) which permits unrestricted, non-commercial use, distribution and reproduction in any medium, provided the work is properly cited. 